\title{
New Prospects for the Study of Leprosy in the Laboratory*
}

\author{
R. J. W. REES \\ Head, Laboratory for Leprosy and Mycobacterial Research \\ National Institute for Medical Research, London, England
}

\begin{abstract}
Although Mycobacterium leprae was identified earlier than Myco. tuberculosis, it has still not been cultured in vitro and only in 1960 was an infection obtained in laboratory animals. However, important advances have been made in the field of experimental leprosy in the last decade due to the development of new techniques and models for studying Myco. leprae in vivo, thus overcoming the limitations imposed by a noncultivable mycobacterium. Quantitative techniques using Myco. lepraemurium provided the first model for developing an indirect method for distinguishing dead (non-infectious) from living (infectious) bacilli, based on morphological differences in organisms stained by the Ziehl-Neelsen method. However, the most important advances resulted from the limited and localized growth of Myco. leprae when inoculated into the footpads of mice and, later, the more substantial and generalized multiplication of Myco. le prae in immunologically deficient mice (thymectomized and irradiated with a dose of $900 \mathrm{r}$ ). Moreover, in the immunologically deficient animals, the infection eventually resulted in a disease replicating that of lepromatous type leprosy in man, including the involvement of peripheral nerves. The results from these studies and the future prospects for the study of leprosy in the laboratory are reviewed in this article.
\end{abstract}

Of the mycobacterial diseases affecting man, leprosy is second only to tuberculosis in presenting a world health problem affecting more than 10 million people, most of whom live in newly developing tropical and subtropical countries. Leprosy is a chronic infectious disease caused by Mycobacterium leprae, an obligatory intracellular parasite often giving rise to virtually no symptoms. Clinically, the disease manifests itself most commonly in the skin, nose, upper respiratory tract and peripheral nerves and its form is related to the capacity of the individual to destroy the organism. The effect on nerves is responsible for the serious disabilities and deformities of the feet, hands and face, and a Scientific Meeting on Rehabilitation in Leprosy (1961) estimated that in at least 25\% of all cases there is some degree of deformity.

It is of interest that Myco. leprae is the only species of mycobacterium which affects nerves in either man or animals. This unique property

*(Reprinted from Bull. Wld Hlth Org., 1969, 40, 785-800, by kind permission of Chief, Technical Publications, WHO.) deserves special study, for it is likely to increase our knowledge both of the organism and of peripheral nerve fibres.

Patients with leprosy present a wide range of symptoms and signs, ranging between one or other of the 2 polar forms of the disease; namely, tuberculoid leprosy, in which there are few bacilli, and lepromatous leprosy, in which the number of bacilli is extremely high. Thus, a study of the pathogenesis of leprosy requires knowledge drawn from a wider range of scientific disciplines than for any of the other mycobacterial diseases. Hitherto, progress has been severely restricted because Myco. leprae cannot, as yet, be grown in vitro and has only been grown in vivo to a limited extent since 1960 (Shepard, 1960a, b). This is unfortunate because the bacterium was one of the first to be linked specifically to a human disease.

It is obvious that, if the causative organism cannot be cultivated or the disease transmitted to experimental animals, neither the bacteriology nor the pathology of the infection can be studied in the laboratory. The lack of success 
with these techniques has seriously limited the scope of fundamental and applied research in the leprosy field since the isolation and identification of causative organisms, and their subsequent cultivation in vitro and in vivo has resulted in the control of most of the bacterial diseases of man. Failure to cultivate and transmit leprosy in the laboratory has not been due to lack of effort. The first attempts were made by Hansen and since then by many bacteriologists and pathologists. From time to time, claims to success have been made but, until recently, none has been upheld although, between 1874 and 1930, all the other important human pathogens were successfully cultured by one means or another. Since 1960, however, techniques have been developed for the transmission of leprosy to animals, and the situation has been transformed.

This review is confined to a consideration of the experimental models developed during the last 10 years which have now reached a stage that permits Myco. leprae to be studied on a sound experimental basis. Although it is still impossible to grow the bacilli in vitro, these models have already contributed significantly to the study of leprosy in man and are likely to contribute even more during the next 10 years. Although the most important advances arose from the development in 1960 of techniques for transmitting leprosy to animals, it was a prerequisite that experimental models using other species of mycobacteria were developed before the laboratory study of human leprosy was started. The study of models, particularly those using Myco. lepraemurium, established the method for determining, indirectly, the infectivity of Myco. leprae and the techniques of tissue culture adapted to the cultivation of human leprosy bacilli.

\section{MODELS BASED ON COMPARATIVE STUDIES WITH MYCO. LEPRAEMURIUM}

An indirect method for determining the viability of leprosy bacilli

Most species of bacteria are completely destroyed when they die within an infected host, but mycobacteria are an exception since they retain both their bacillary form and the property of staining with carbol fuchsin when they are no longer alive. However, in a Myco. le prae infection it was not possible to determine directly whether bacilli in the patient were alive or dead because they could not be cultured. Therefore, indirect methods for measuring their viability had to be used. For these studies the closely related Myco. lepraemurium proved to be an ideal model since, although the rat leprosy bacillus also failed to grow in vitro, its viability could be assessed in terms of infectivity by determining its ability to produce disease following its reinoculation into animals. Early studies using electron microscopy showed that viable Myco. lepraemurium, that is, bacilli that infected animals, could readily be distinguished from non-viable bacilli, that is, bacilli that failed to infect animals (McFadzean and Valentine, 1959; Rees, Valentine and Wong, 1960). The essential differences were that the cell wall of the noninfectious (i.e. dead) bacillus, though still intact, was no longer uniformly filled but contained only electron-dense aggregates of disorganized protoplasmic material, whereas the infectious form was uniformly electron-dense. Evidence that this was a general phenomenon was provided by using an entirely different species of bacterium, Escherichia coli, which had the added advantage that viability could quickly be tested by means of conventional viable colony counts on solid media. The results of such studies showed that there was a close correlation between the decrease in the number of colonies and the increase in the proportion of degenerate forms of $E$. coli seen under the electron microscope. Furthermore, the degenerate changes which took place in $E$. coli resembled those seen in $M y c o$. lepraemurium (Rees, Valentine and Wong, 1960).

Once it had been established that living and dead forms of bacilli could be distinguished, a new set of comparisons was undertaken to see how far the morphological changes seen under the electron microscope were correlated with those shown by the light microscope when Myco. lepraemurium was stained with carbol 
fuchsin using the routine Ziehl-Neelsen method. Rees and Valentine (1962) developed a new technique that allowed individually identified and stained bacilli to be examined first under the light microscope and then under the electron microscope. Close agreement was found between the proportion of degenerate forms of Myco. lepraemurium seen under the electron microscope and the proportion of bacilli showing irregular staining with carbol fuchsin under the light microscope. From these studies it appeared that the electron-dense material within the cell wall of the organism corresponded exactly to the part staining with carbol fuchsin. It was therefore concluded that all forms of Myco. lepraemurium showing irregular staining were dead and only those showing uniform or "solid" staining were likely to be viable. It was reasonable to expect that this assumption could be extended to the human leprosy bacillus since the same morphological changes were likely to be shared by all species of mycobacteria. This expectation was fully confirmed when, using the same technique, suspensions of Myco. leprae were examined by both light and electron microscopy (Rees and Valentine, 1962). More recently, it has been possible to confirm this assumption by demonstrating experimentally that only the uniformly staining forms of Myco. leprae are capable of multiplying in the mouse footpad (Rees, 1965b; Shepard and McRae, 1965).

\section{Rate of multiplication of leprosy bacilli in vivo}

One explanation for the chronicity of human leprosy might be that Myco. leprae divides more slowly than other bacteria or even other mycobacteria; this hypothesis could be tested in murine leprosy since the natural and experimental infections are known to be chronic. By applying quantitative techniques it has been possible to follow the total number of stained acid-fast bacilli in the tissues of animals during the infection and therefore to determine the rate of multiplication or the generation time of Myco. lepraemurium. Several different groups of workers (Hilson and Elek, 1957; Hobby et al., 1954; Rees, 1957) have found that even in susceptible animals, the bacilli divide only every
10 to 14 days. This very long generation time is unique for micro-organisms and even for other species of mycobacteria. It is most unlikely that Myco. leprae would have a shorter generation time than that of Myco. lepraemurium. The long generation time must be considered when claims of successful cultivation or transmission of Myco. leprae are being assessed, particularly if the claim suggests that the organism is multiplying rapidly. It is even more important to accept a long generation time when methods for attempting to cultivate or transmit Myco. leprae are being planned. The model has been shown to be applicable by Shepard and McRae (1965), who demonstrated that Myco. leprae has a generation time of 13 to 25 days in the mouse footpad (see p. 144).

Time taken to kill leprosy bacilli and the fate of dead organisms following chemotherapy

It is known that in patients receiving successful chemotherapy, in particular after treatment with diaminodiphenylsulfone, a very long time elapses before bacilli disappear from the lesions. Whether this was due to the slow rate at which the drug killed the bacilli or to the inability of the host to dispose of the dead organisms could only be a matter of conjecture in the absence of direct or indirect evidence. However, when murine leprosy was used as a model to study the effect of chemotherapy on the rate of kill (as determined by the proportion of irregularly stained, "dead", bacilli) and the ability of the host to dispose of the bacilli killed by chemotherapy in vivo (Rees and Waters, 1963), indirect evidence on this point became available. Mice heavily infected with Myco. lepraemurium were treated with isoniazid and the total number of bacilli and the total numbers of viable (solidly staining bacilli) were determined in the treated and untreated groups at regular intervals for more than a year. The results showed that isoniazid was very effective since the untreated animals all died of gross infection within 100 days, whereas the treated mice lived for more than a year. Furthermore, $73 \%$ of the bacilli in the treated mice showed irregular staining after only 28 days and the proportion 


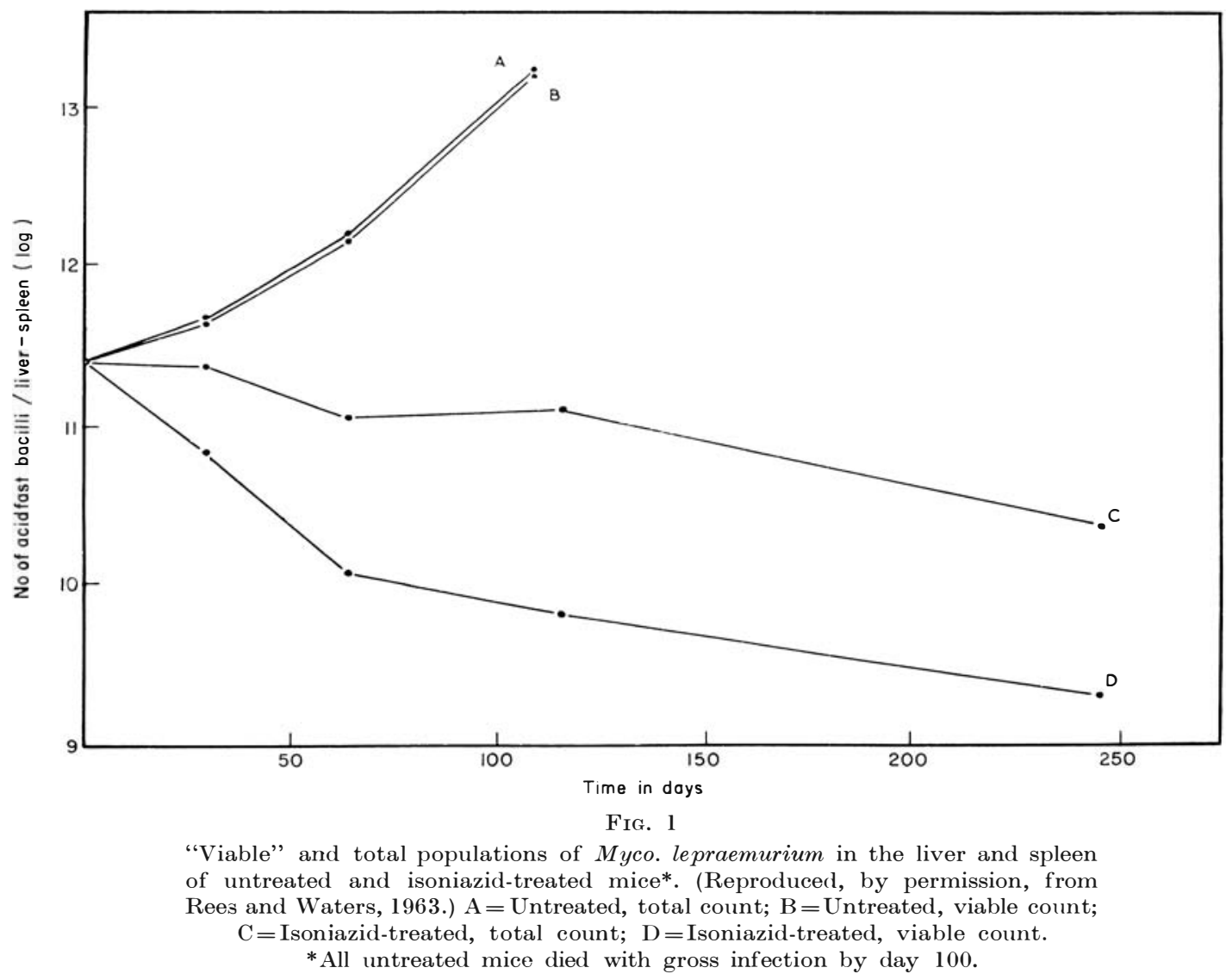

had reached $93 \%$ by the 63 rd day of treatment. There was, therefore, a $90 \%$ kill within 50 days of treatment. On the other hand, the fall in the total number of stained bacilli in the tissues of the treated mice was much slower; it took 250 days for a $90 \%$ fall in numbers to occur (Fig. 1). Thus, although isoniazid was effectively bactericidal within a relatively short time, dead Myco. lepraemurium were not nearly so quickly removed from the infected tissues. After continuous treatment with isoniazid for 1 year the proportion of solidly staining acid-fast bacilli started to rise again; in other words, viable organisms were reappearing. The total number of such organisms steadily increased and within 3 months the animals died of Myco. lepraemurium infections. Bacilli recovered from animals that had relapsed under treatment with isoniazid were inoculated into healthy mice which were also treated with isoniazid. These animals showed no response to the drug and the infections took the same course as in untreated controls (Hart, Rees and Valentine, 1962). This indicated, without doubt, that the recurrence of active disease in the mice used in the first experiment was due to the appearance of isoniazid-resistant organisms and that the relapse was heralded by the reappearance of bacilli which were morphologically viable.

Use of tissue culture systems for the cultivation of Myco. lepraemurium in vitro

Myco. lepraemurium, like Myco. leprae, is predominantly an intracellular parasite and so far neither organism has been cultured in bacteriological media. The dependence on an intracellular environment strongly suggested that tissue-culture methods might offer a means 
of growing Myco. lepraemurium in vitro. The first successful claims of limited multiplication of Myco. lepraemurium in tissue culture systems were made by Wallace, Elek and Hanks (1958) and by Rees and Wong (1958). Since then, techniques have been developed using an established strain of rat fibroblast cells (Rees and Garbutt, 1962) or cultures of mouse macrophages (Chang, 1960) in which indefinite and continuous multiplication of Myco. lepraemurium has been obtained. The success of these tissue-culture methods for Myco. lepraemurium provides a wealth of knowledge which can be applied directly to the problems concerned with the very similar, slow-growing organism Myco. leprae. In particular, the studies have stressed the importance of using quantitative methods for determining the total number of acid-fast bacilli present at the beginning and at the end of each culture period, and therefore basing multiplication on absolute increases in the bacillary population. The value of examining the morphology of the bacilli as a sensitive means of determining their survival in tissue culture has also been made clear. It is significant that the characteristics of Myco. lepraemurium maintained in continuous cultivation in tissueculture systems for more than 3 years have not changed (Rees and Garbutt, 1962). Myco. lepraemurium grown in tissue culture do not multiply in bacteriological media, still have a generation time of 10 to 12 days and retain their pathogenicity for mice and rats. These observations are of considerable importance since they confirm the generally accepted view of the stability of bacterial populations, which is in sharp contrast to so many of the acid-fast bacillary strains, claimed to be Myco. leprae, which were isolated from leprosy patients. These strains had a wide and variable range of characteristics which were, unjustifiably, explained on the basis of adaptation or mutation.

Application of the results of studies on murine leprosy to human leprosy

Myco. lepraemurium has been extensively used as a model in leprosy research, although more recently its value has been criticized. Such criticism is justifiable only when murine leprosy has been used uncritically as a model for the human infection-namely, for screening potential antileprosy drugs and in comparative pathological and histological studies. Where murine leprosy has been used to answer specific questions or to test hypotheses directly related to Myco. leprae, these studies have provided valuable information. It is clear from the results of these studies that a new and valuable technique was available that could now be used in man to determine the viability of Myco. leprae in patients and thus to assess precisely their probable response to chemotherapy, the infectivity of the various types of leprosy, and, by histological studies, the viability of Myco. leprae in different tissues. Thus the morphological index (MI), that is, the percentage of solidly staining bacilli seen in smears or sections from leprosy patients, could now be used as the measure of viability.

The routine bacteriological examination of patients is based on smears prepared from diseased skin or a nasal scraping and, after staining the smear by the carbol fuchsin method, the density of bacilli (this is known as the bacteriological index (BI) is scored, irrespective of the morphological appearance of the bacilli. The progress of the patient under treatment is then judged by the rate of disappearance of bacilli from these smears, that is, by the fall in the BI. It has long been considered that even the most active antileprosy drugs, including diaminodiphenylsulfone, leave much to be desired since in patients with the more severe lepromatous type of leprosy many years elapse before negative smears give evidence of a "cure". Hitherto, it has been assumed that more active drugs are required to kill Myco. leprae more rapidly than diaminodiphenylsulfone, an assumption that was based on the fact that the BI falls so slowly. Now that it has been demonstrated conclusively that the viability of Myco. leprae can be assessed on the basis of their morphology rather than on the total number of the bacilli, it has been possible to show, in carefully controlled studies, that a very high proportion of bacilli are killed in 3 months in 


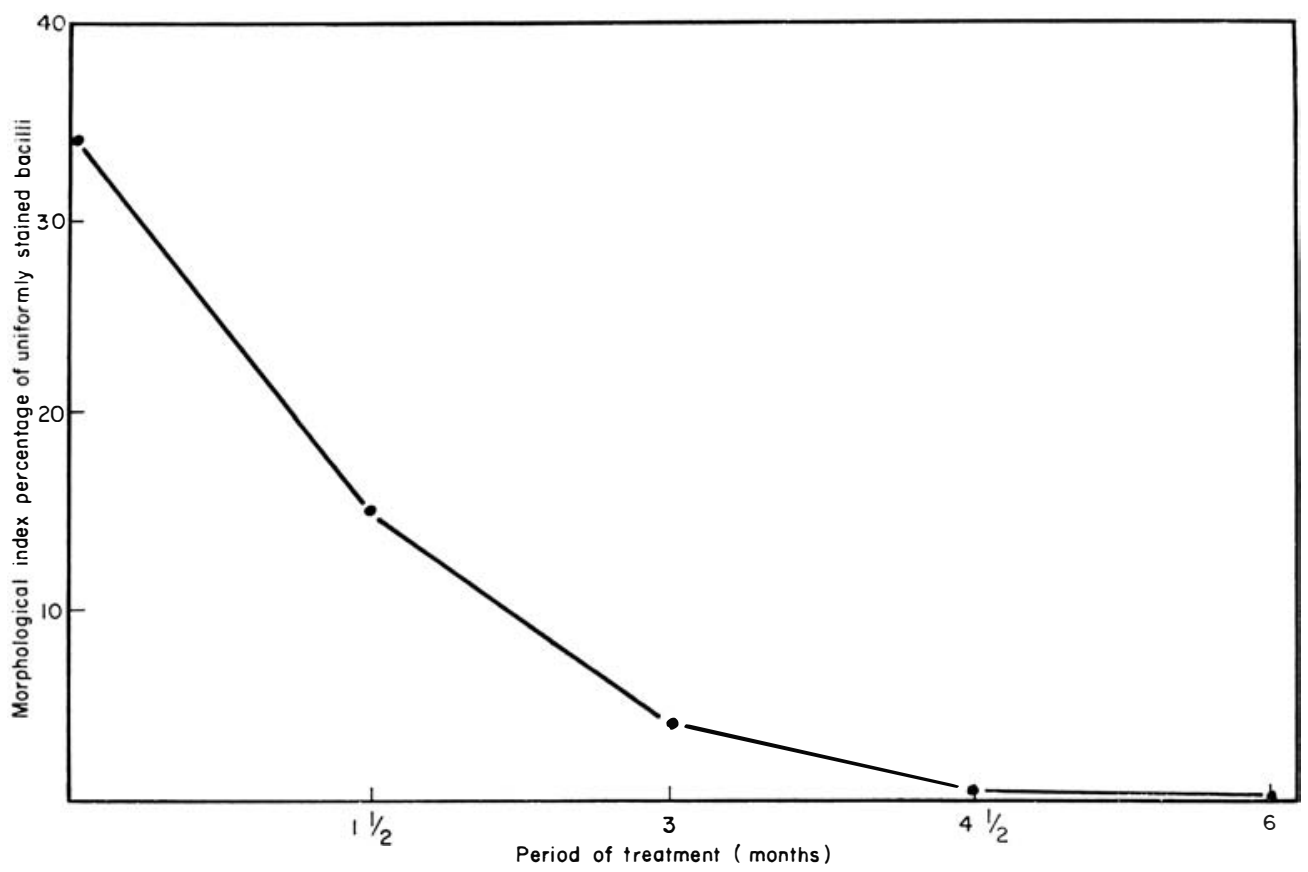

Fig. 2

Effect of treatment with diaminodiphenylsulfone $(100 \mathrm{mg}$ daily) for 6 months on the Morphological Index (MI) in 6, previously untreated, lepromatous patients. ( $100 \mathrm{mg}$ daily).

patients receiving standard treatment with diaminodiphenylsulfone (Waters and Rees, 1962). This observation suggests that persisting lesions and many of the manifestations of leprosy, including reactions of the erythema nodosum leprosum type, that follow the initial phase of chemotherapy must be due, in part, to the presence of dead bacilli. It implies that a more rapid cure will be achieved only if other drugs or methods are found that could be used, after the initial killing of leprosy bacilli with standard antileprosy drugs, to enhance the host's ability to dispose of dead, but still intact, leprosy bacilli.

Thus the introduction of the MI as an index of viability has not only provided a rapid method for determining, within a period of only 3 to 6 months (Fig. 2), the activity of potential antileprosy drugs (Waters, Rees and Sutherland, 1967) but has led to an entirely new approach to the problem of leprosy chemotherapy. Furthermore, an increase in the MI during treatment provides a sensitive measure of the patient's deterioration, whether this is due to failure to take the drug or to the emergence of drug resistance (Pettit and Rees, 1964; Pettit, Rees and Ridley, 1966) (see p. 146).

\section{EXPERIMENTAL LEPROSY IN ANIMALS}

Before describing advances that have been made in the field of experimental transmission of leprosy to animals since 1960 , it is pertinent to review briefly the general problems and methods used in animal transmission experiments and the criteria for assessing successful claims. These were defined in detail by the Technical Committee on Pathology and Experimental Transmission (1963) at the Eighth International Congress of Leprology in Rio de Janeiro, Brazil. Bacilli for inoculating laboratory animals should be obtained from patients with untreated leprosy and with a high MI and, because of the possible contamination of skin by other cultivable mycobacteria, biopsy specimens should not be taken 
from ulcerated lesions. Moreover, all suspensions prepared for purposes of inoculation should be cultured on a variety of media suitable for isolating mycobacteria. In addition to each group of animals inoculated with fresh suspensions of bacilli, there should be a group inoculated with heat-killed organisms and an uninoculated group of animals. Quantitative bacteriological methods should be used in order to determine the number of organisms inoculated and subsequently to determine the number of organisms present in the animals. These rigorous methods and checks were introduced in order to exclude as far as possible the inoculation and subsequent development of infections with contaminating strains of mycobacteria, and also the possibility that the animals themselves might be carriers of mycobacteria. This latter possibility has been demonstrated very clearly by the elegant work of Nishimura and his colleagues working at Osaka in Japan, showing that a proportion of apparently healthy mice and other rodents can be carriers of a murine leprosy-like infection (Nishimura et al., 1964). The criteria for assessing successful claims for transmission of leprosy were also rigorously defined. In addition to counting the number of bacilli isolated from the animal tissues, the organisms should be cultured, using again media suitable for growing mycobacteria. Successful transmission of an infection from one patient should be reproduced from others, using the same experimental conditions. A standard type lepromin should be prepared from the bacilli harvested from the animals and compared with a similarly prepared human lepromin from patients with tuberculoid and lepromatous leprosy; these tests should be carried out and read blindly. Finally, a histopathological examination should be made of the infected tissues including, in particular, a careful examination of the nerves, using the requisite staining methods.

\section{Experimental leprosy in normal animals}

Undoubtedly the most important direct contribution to the study of leprosy since the identification of Myco. leprae by Hansen has been the transmission of experimental leprosy to animals. This was achieved first by Shepard $(1960 a, 1960 b)$, at the Communicable Disease Center, Atlanta, Ga., USA, who showed that a reproducible and limited infection could be produced when the footpads of mice were inoculated with Myco. leprae. Moreover, an identical type of infection has now been produced in other centres throughout the world.

\section{General features}

The infection obtained in the mouse footpad is a local one and is dependent upon the number of bacilli inoculated. Thus inocula of $5 \times 10^{3}-10^{4}$ Myco. leprae multiply 100 -fold in 6 to 8 months, whereas larger inocula fail to give a higher yield, and inocula of $10^{6}$ bacilli fail to show any multiplication. Moreover, having multiplied as far as they are able, the bacilli gradually die (Rees, 1964). A similar type of infection has been obtained subsequently in the ears of mice and in the ears and footpads of hamsters (Waters and Niven; 1965, 1966) and in the footpad of the rat (Hilson, 1965). Although these experimental infections give only limited multiplication of Myco. leprae, they are reproducible and can be maintained indefinitely in the laboratory by passage and are adaptable to quantitative analysis. It is probable that more than 200 strains of Myco. le prae derived from individual patients with active disease originating from nearly every part of the world have produced an identical type of infection when inoculated into footpads of mice. For example, in our own series we obtained successful transmission with all 89 strains of bacilli isolated from individual patients with active leprosy from different parts of the world and with different types of the disease (79 patients with lepromatous leprosy and 10 with borderline tuberculoid leprosy). The sources of the 89 strains is shown in the following tabulation.

$\begin{array}{cc}\text { Origin } & \text { No. of strains } \\ \text { Africa } & \\ \text { Central } & 1 \\ \text { East } & 1 \\ \text { West } & 3\end{array}$




$\begin{array}{lr}\text { Burma } & 6 \\ \text { India } & 8 \\ \text { Malaysia } & 66 \\ \text { Malta } & 1 \\ \text { Pakistan } & 1 \\ \text { Samoa } & 1 \\ \text { West Indies } & 1\end{array}$

These results are important since they indicate that the virulence of strains of Myco. leprae for the mouse is similar, irrespective of whether the strains were derived from patients with the more tuberculoid or more lepromatous form of the disease, thus suggesting that the pattern of disease in man is determined by the host and not by the parasite. However, these findings do not exclude the possibility of strain difference in Myco. leprae of the type, for example, that has been shown with Myco. tuberculosis in animals where both Myco. tuberculosis hominis and Myco. tuberculosis bovis are virulent in the guinea-pig but only the latter is virulent in the rabbit.

The evidence that the infection produced in the footpads or ears of various rodents, including the mouse, rat and hamster, is overwhelmingly in favour of the infection being due to the human leprosy bacillus. Although this is now universally accepted, it is important to recapitulate the criteria which were used to establish this evidence and the care that was taken by those working in the field to satisfy all the criteria that are outlined in the following section. The criterion of bacterial multiplication was based on precise quantitative methods so that the number of bacilli inoculated could be compared with the number finally harvested in the footpads of mice. The pattern and rate of multiplication were uniformly reproducible with all strains of Myco. le prae derived from untreated patients. All the inocula and harvests were cultured on media suitable for isolating mycobacteria, in order to exclude the possibility that the infection was caused by a cultivable organism. Lepromin prepared from bacilli harvested from the mouse footpad infections was compared with standard Mitsuda-type lepromin prepared from man in a series of patients with different types of leprosy and the pattern of response was identical (Shepard and Guinto, 1963). The histology of the footpad infection in mice was also studied and the pattern of response was shown to be similar for all strains of Myco. leprae and, although the cellular changes were indeterminate and not characteristic of the polar types of leprosy as seen in man, they were not characteristic of those produced by any other known species of mycobacteria (Rees and Weddell, 1968). Moreover, in a proportion of the infected animals acid-fast bacilli were found, occasionally late on in the infection, within nerves of the footpad or in the sciatic nerve (Wiersema et al., 1965; Rees and Weddell, 1968) and therefore showed a selectivity for peripheral nerves shared by no other species of mycobacteria.

Although the infection produced by the local inoculation of Myco. le prae into the ears or footpads of rodents was a limited one and multiplication only occurred when the number of bacilli inoculated was less than $10^{6}$, bacilli could be harvested from these infections and reinoculated into animals, where again they multiplied and reproduced the same bacteriological and histological patterns of response. Therefore, because the characteristics of Myco. leprae were not changed by serial passage, this method could be used for maintaining in definitely experimental infections with Myco. leprae for study in the laboratory (Rees, 1965b; Shepard, 1965b). Moreover, a similar pattern of infection has been obtained in the many different strains of mice used although more detailed comparisons suggest that the CBA and BALB/C strains of mice are the most susceptible (Shepard and Habas, 1967).

\section{RECENT APPLICATIONS OF INFECTIONS IN THE FOOTPADS OF MICE FOR THE STUDY OF MYCO. LEPRAE}

Once it was established that Myco. leprae could be transmitted to animals it was hoped that this experimental infection would provide the first opportunity for studying Myco. leprae in the laboratory. These hopes have been fully justified; 
within less than 10 years, despite the limited nature of experimental human leprosy in normal animals, this in vivo technique has provided new information of great importance concerning the properties of Myco. leprae. For practical reasons the mouse footpad infection with Myco. leprae has been chosen by most laboratories working in this field.

\section{Generation time of Myco. leprae}

During the logarithmic phase of multiplication in the mouse footpad a generation time of 13 to 25 days has been observed (Shepard and McRae, 1965). This very long generation time is consistent with the chronicity of the disease and the long incubation period observed in man and, although comparable to the generation time of Myco. lepraemurium it is otherwise unique, even for the slowly multiplying Mycobacteriaceae.

\section{Drug sensitivity testing}

The footpad infection, in spite of its limited nature, has been used successfully for testing drugs for antileprosy activity. Thus it has been shown that when Myco. le prae is injected into the footpads of mice treated with known antileprosy drugs the organisms fail to multiply. Therefore, the mouse footpad infection provides, for the first time, a specific test for screening new antileprosy drugs and the search is no longer restricted to drugs that are known to be active against Myco. tuberculosis (Table 1). Hitherto, chemotherapy in leprosy had necessarily evolved from an entirely empirical basis and even the regimen of treatment with diaminodiphenylsulfone, which has been the standard used for leprosy since 1943, was established by trial and error. This was due to the fact that although diaminodiphenylsulfone has slight in vitro and

TABLE 1

Tests of activity of drugs against Myco. leprae using the mouse footpad technique

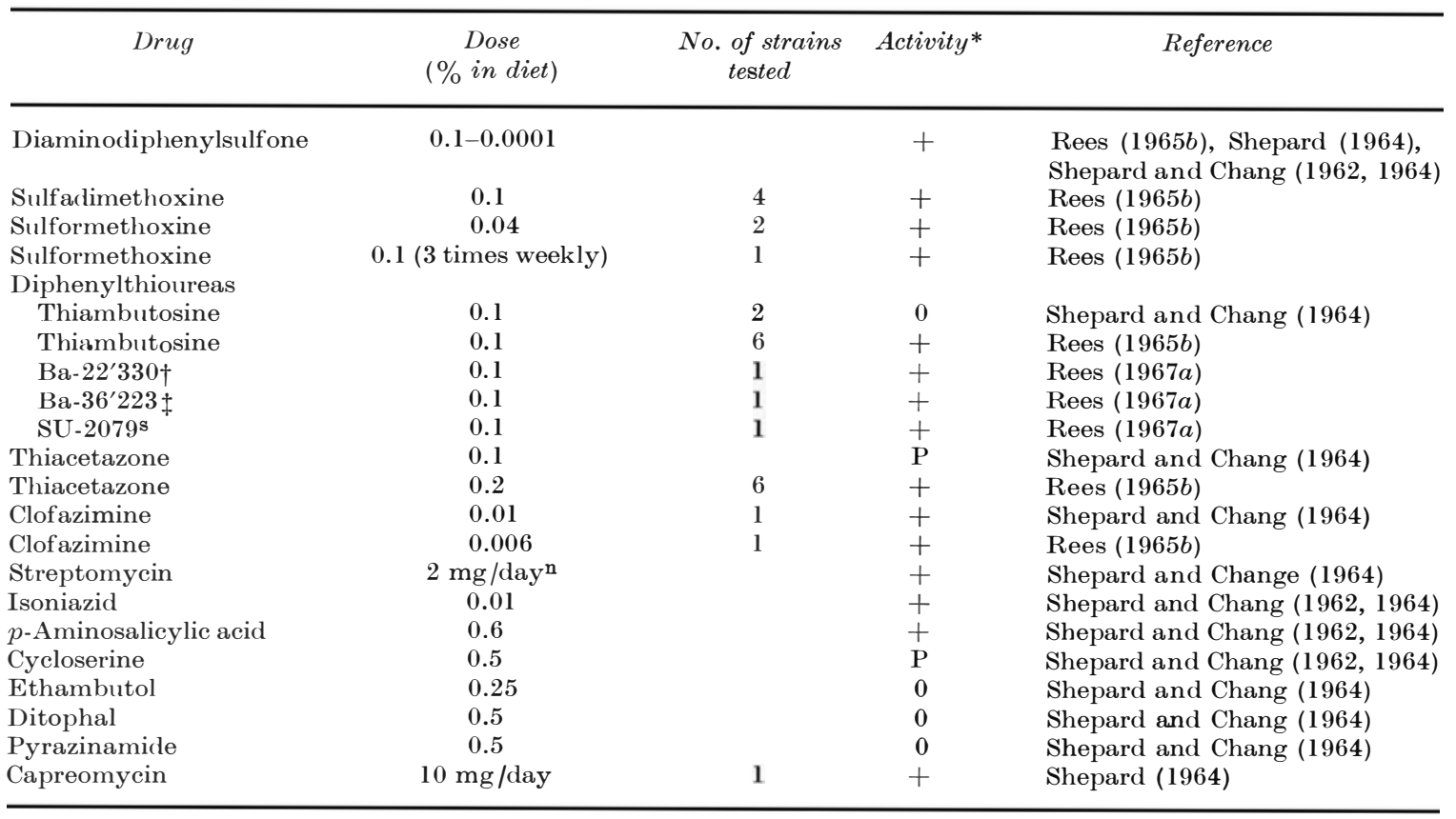

$*+=\mathrm{F}$ ull activity; $\mathrm{P}=$ partial activity; $0=$ inactive.

$\dagger \mathrm{Ba}-22^{\prime} 330=4$-(3-carboxypropoxy)-4'-dimethylamino-diphenylthiourea $\ddagger$ Ba-36'223 = 4-dimethylamino-4'-(4-hydroxybutoxy)-dephenylthiourea sSU-2079=4-butoxy-4'-diethylaminoethoxy-diphenylthiourea thiambutosine metabolites. nOnce-daily injections. 
in vivo activity against Myco. tuberculosis in guinea-pigs, it is ineffective against tuberculosis in man. Thus on an empirical basis it has been accepted that the standard dose of diaminodiphenylsulfone should be $100 \mathrm{mg}$ daily; however, there are important practical and clinical advantages to be gained by modifying this regimen. For example, intermittent treatment with diaminodiphenylsulfone could more easily be supervised than daily treatment. Furthermore, leprologists are now tending to advocate smaller doses of diaminodiphenylsulfone because these appear to reduce the frequency and severity of acute reactions (exacerbation) with their attendant nerve and eye complications but are equally effective in controlling the disease. On account of these trends, the mouse footpad technique is used not only for screening drugs but has also been specifically applied to determine, for the first time, the minimal inhibitory concentration (MIC) of diaminodiphenylsulfone in vivo against strains of Myco. leprae from previously untreated patients (Shepard, 1967b; Rees, 1967a, 1967b). The sensitivities of 5 "wild" strains of Myco. leprae from patients in Malaysia were tested in this way using concentrations of $0.0001 \%$ and $0.00001 \%$ of diaminodiphenylsulfone in the diets of the mice. The results are shown in the following tabulation:

$\begin{array}{cll}\text { Strain } & 0.0001 \% & 0.00001 \% \\ 1 & \text { Sensitive } & \text { Sensitive } \\ 2 & \text { Sensitive } & \text { Resistant } \\ 3 & \text { Sensitive } & \text { Resistant } \\ 4 & \text { Sensitive } & \text { Resistant } \\ 5 & \text { Sensitive } & \text { Resistant }\end{array}$

The MIC was determined by feeding groups of mice with diminishing concentrations of diaminodiphenylsulfone in their diet and determining the concentrations of diaminodiphenylsulfone in the sera of each group. The results of these studies are shown in Table 2, from which it is clear that the MIC for diaminodiphenylsulfone against wild strains of Myco. leprae is approximately $0.015 \mu \mathrm{g} / \mathrm{ml}$. Thus, Myco. leprae in the mouse is exquisitely sensitive to diaminodiphenylsulfone; an unexpected finding, because
TABLE 2

Concentration of diaminodiphenylsulfone in the sera of mice fed different levels of drug in the diet

\begin{tabular}{|c|c|c|}
\hline $\begin{array}{l}\text { Dose of diaminod } \\
\text { Percentage } \\
\text { in } \\
\text { diet* }\end{array}$ & $\begin{array}{l}\text { phenylsulfone } \\
\qquad \mathrm{Mg} / \mathrm{kg} \\
\text { of } \\
\text { body-weight }\end{array}$ & $\begin{array}{l}\text { Concentration of } \\
\text { diaminodiphenyl- } \\
\text { sulfone in serum } \\
\text { or plasma }\end{array}$ \\
\hline 0.1 & 200.0 & 12.5 \\
\hline 0.025 & 50.0 & 3.3 \\
\hline 0.01 & 20.0 & $1.0 \dagger$ \\
\hline (Man: $100 \mathrm{mg} /$ day) & $(2.0)$ & $(1.5)$ \\
\hline 0.001 & 2.0 & $0.015 \dagger$ \\
\hline 0.0001 & 0.2 & $0.015 \dagger$ \\
\hline (Man: $1 \mathrm{mg} /$ day) & $(0.02)$ & $(0.018) \dagger$ \\
\hline 0.00001 & 0.002 & $(0.0015) \ddagger$ \\
\hline
\end{tabular}

$* \mathrm{~g} / 100 \mathrm{~g}$.

†Estimated by Glazko's method.

‡Calculated concentration. Serum concentration varies linearly with doses between $0.1 \%$ and $0.0001 \%$. Actual value is below level of detectability.

all other species of mycobacteria are relatively insensitive to sulfones and even the diaminodiphenylsulfone-sensitive micro-organisms such as group A streptococci (Francis and Spinks, 1950) and Plasmodium berghei (Thompson, Oleszewski and Waitz, 1965) are 3 to 100 times less sensitive than Myco. leprae to diaminodiphenylsulfone. The standard treatment of $100 \mathrm{mg}$ of diaminodiphenylsulfone per day for man gives serum concentrations of approximately $1.5 \mu \mathrm{g} / \mathrm{ml}$. Assuming that it is permissible to extrapolate these findings from mouse to man, they suggest that a daily dose of $1 \mathrm{mg}$ of diaminodiphenylsulfone would be effective in man. This means that there is strong support from the animal studies for encouraging trials, using lower doses of diaminodiphenylsulfone in man, to reduce the incidence of reactions without the fear of diminishing the therapeutic efficacy of the drug.

\section{Drug-resistant strains of Myco. leprae}

The result which has emerged from the systematic investigation of footpad infections has been direct proof of the existence of drugresistant strains of Myco. leprae. Carefully controlled investigations on specially selected patients who showed active disease despite treatment with diaminodiphenylsulfone for at 
TABLE 3

Sensitivity of strains of Myco. leprae from relapsed diaminodiphenylsulfone-treated patients* to diaminodiphenylsulfone $\dagger$

\begin{tabular}{|c|c|c|c|c|c|c|c|}
\hline \multirow[t]{2}{*}{ Strain } & \multirow{2}{*}{$\begin{array}{l}\text { Country of } \\
\text { origin }\end{array}$} & \multicolumn{6}{|c|}{ Sensitivity to diaminodiphenylsulfone: percentage of drug in the diet } \\
\hline & & 0.1 & 0.025 & $0.01 \ddagger$ & 0.001 & 0.000 & 0.00001 \\
\hline 1 & & $\mathrm{R}$ & $\mathrm{R}$ & & & & \\
\hline 2 & & $\mathrm{R}$ & & & & & \\
\hline 3 & Malaysia & $\mathrm{R}$ & & & & & \\
\hline 4 & & $\mathrm{~S}$ & $\mathrm{R}$ & & & & \\
\hline 5 & & $\mathrm{~S}$ & $\mathrm{R}$ & & & & \\
\hline 6 & India & $\mathrm{R}$ & $\mathrm{R}$ & & & & \\
\hline 7 & Malaysia & & $\mathrm{R}$ & $\mathrm{R}$ & & & \\
\hline 8 & India & & $\mathrm{s}$ & $\mathrm{R}$ & & & \\
\hline 9 & West Africa & & $\mathrm{R}$ & $\mathrm{R}$ & $\mathrm{R}$ & & \\
\hline 10 & India & & $\mathrm{s}$ & $\mathrm{R}$ & & & \\
\hline 11 & & & $\mathrm{~S}$ & $\mathrm{R}$ & $\mathrm{R}$ & $\mathrm{R}$ & $\mathrm{R}$ \\
\hline 12 & & & $\mathrm{~s}$ & $\mathrm{R}$ & $\mathrm{R}$ & $\mathrm{R}$ & $\mathrm{R}$ \\
\hline 13 & & & $\mathrm{~S}$ & $\mathrm{R}$ & $\mathrm{R}$ & $\mathrm{R}$ & $\mathrm{R}$ \\
\hline 14 & & & $\mathrm{~s}$ & $\mathrm{R}$ & $\mathrm{R}$ & $\mathrm{R}$ & $\mathrm{R}$ \\
\hline 15 & Malaysia & & $\mathrm{s}$ & $\mathrm{R}$ & $\mathrm{R}$ & $\mathrm{R}$ & $\mathrm{R}$ \\
\hline 16 & & & $\mathrm{R}$ & $\mathrm{R}$ & $\mathrm{R}$ & $\mathrm{R}$ & $\mathrm{R}$ \\
\hline 17 & & & $\mathrm{R}$ & $\mathrm{R}$ & $\mathrm{R}$ & $\mathrm{R}$ & li \\
\hline 18 & & & $\mathrm{R}$ & $\mathrm{R}$ & $\mathrm{R}$ & R & $\mathrm{R}$ \\
\hline 19 & & $\mathrm{~S}$ & & $\mathrm{R}$ & $\mathrm{R}$ & $\mathrm{R}$ & $\mathrm{R}$ \\
\hline
\end{tabular}

* All these patients failed to respond bacteriologically, histologically or clinicially to a rigorously controlled period of not less than 6 months on a supervised dose of $600 \mathrm{mg}$ of diaminodiphenylsulfone per week.

†A dosage of $0.01 \%$ of diaminodiphenylsulfone in the diet of mice gives a serum concentration of $1 \mu \mathrm{g} / \mathrm{ml}$ ard is therefore of the same order as the concentration in man on a regimen of $100 \mathrm{mg} /$ day. Thus the level of resistance in the 19 strains of Myco. leprae determined in mice is consistent with the therapeutic failure of diaminodiphenylsulfone in the patients.

$\ddagger \mathrm{S}=$ sensitive; $\mathrm{R}=$ resistan $\mathrm{t}$.

least 10 years, combined with studies on the diaminodiphenylsulfone sensitivity of bacilli from these patients using the mouse footpad technique, have shown that a proportion of such patients are infected with diaminodiphenylsulfone-resistant strains of bacilli (Pettit and Rees, 1964; Pettit, Rees and Ridley, 1966; Adams and Waters, 1966; Rees, 1967b). To date, 19 diaminodiphenylsulfone-resistant strains from individual patients in different parts of the world have been detected using the mouse footpad test (Table 3). From the data presented in Table 2 on the serum levels obtained in patients on regimens of $100 \mathrm{mg}$ of diaminodiphenylsulfone daily $(1.5 \mu \mathrm{g} / \mathrm{ml})$, and from the MIC of diaminodiphenylsulfone for wild strains of Myco. leprae calculated from the footpad test $(0.015 \mu \mathrm{g} / \mathrm{ml})$, relapses under such doses of diaminodiphenylsulfone in man due to the emergence of drug-resistant strains, gives a resistance ratio of 100 . The results from Table 3 show clearly that the degree of resistance developed by all 19 strains had a resistance ratio of not less than 100. The relevant data on resistance studies which show that the correlation between studies in man and mouse are satisfactory, are summarized opposite.

Although the mouse footpad test has provided the first direct evidence of the emergence of resistance to diaminodiphenylsulfone, the phenomenon appears to be rare, and may have resulted from the use of excessively high doses of diaminodiphenylsulfone. It has to be admitted that the use of smaller doses of diaminodiphenylsulfone, resulting in concentration of diaminodiphenylsulfone in the serum and tissues nearer to the MIC of diaminodiphenylsulfone for Myco. leprae, could lead to the emergence of a greater number of resistant strains. This possibility must be weighed against the advantages to be gained by a significant diminution in the incidence of serious reactions that are 


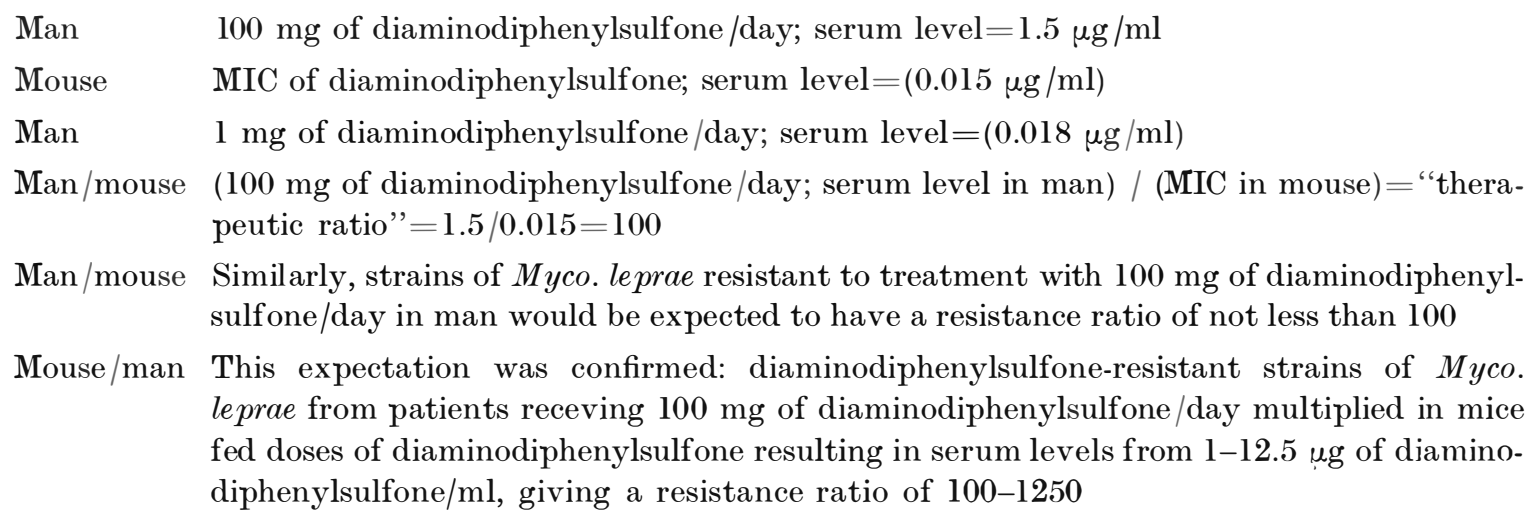

believed to be directly related to high doses of diaminodiphenylsulfone.

Similar but less extensive studies have demonstrated the emergence of thiambutosineresistant strains of Myco. leprae (Rees, 1967a, 1967b): such strains show cross-resistance to thiacetazone, a feature shared by thiambutosine-resistant strains of Myco. tuberculosis (Konopka et al., 1955).

Effect of BCG vaccination against Myco. leprae

The footpad infection technique provides an experimental model for investigating the prophylactic effects of various vaccines and has already demonstrated that vaccination by BCG significantly inhibits the multiplication of Myco. leprae (Shepard, 1965a, 1966). This finding is important although it is not unique since it has already been shown experimentally that vaccination by BCG can produce protective immunity against species of mycobacteria other than Myco. tuberculosis (Fenner, 1957). Still more recently, Shepard and Ribi (1968) have shown that vaccination with the cell-wall fraction of BCG incorporated in an oily base is as protective as living BCG, weight for weight, against infections with Myco. leprae in the footpads of mice. Thus, mouse footpad infections with Myco. leprae provide an important model for investigating the value of prophylactic vaccinations against human leprosy which, if they could eventually be applied to man, would be expected to play a major role in the eradication of the disease. The current importance of these experimental observations that BCG prevents the multiplication of Myco. leprae in the mouse footpad is that they support the preliminary results in man that BCG vaccination significantly reduces the incidence of early type leprosy in child contacts in Uganda (Brown and Stone, 1966; Brown, Stone and Sutherland, 1968).

\section{EXPERIMENTAL LEPROSY IN MICE WITH REDUCED IMMUNOLOGICAL CAPACITY}

The successful transmission of human leprosy to animals in 1960 provided the first and only means of studying Myco. leprae in the laboratory. Although this experimental model has, in less than a decade, provided more information on the human leprosy bacillus than was available previously, progress in the field of leprosy research was still restricted by the limited nature of the infection. Clearly, the next step was to determine the factor or factors preventing Myco. le prae from multiplying freely in mice or in other rodents. On the assumption that the infection was limited by the development of immunity, various methods for reducing the immunological capacity of mice were investigated in an attempt to enhance the infection. The assumption was confirmed when it was demonstrated that enhanced infections with Myco. le prae could be obtained in mice following thymectomy and wholebody irradiation (with $900 \mathrm{r}$ ) as a means of reducing their immunological capacity. 
General features of the infection in thymectomized irradiated mice inoculated with $\mathbf{M y c o}$. leprae

It has now been established (Rees, 1965a, 1965b; Rees and Weddell, 1968; Rees et al., 1967) and confirmed (Gaugas, 1967; Shepard and Congdon, 1968) that when the immunological capacity of mice is reduced by thymectomy plus irradiation (with $900 \mathrm{r}$ ), Myco. leprae inoculated locally into the footpads or ears multiply more freely and yield 100 to 1000 times more bacilli per site than in normal animals (Fig. 3), and that in due course the infection spreads to other sites. Moreover, similarly treated mice become heavily infected in specific sites when inoculated intravenously with Myco. leprae (Rees and Weddell, 1968; Rees et al., 1967). Although, in these animals, the generation time is not reduced, the bacilli continue to multiply for a longer period. The spread of infection, in locally inoculated animals, is also highly selective. The

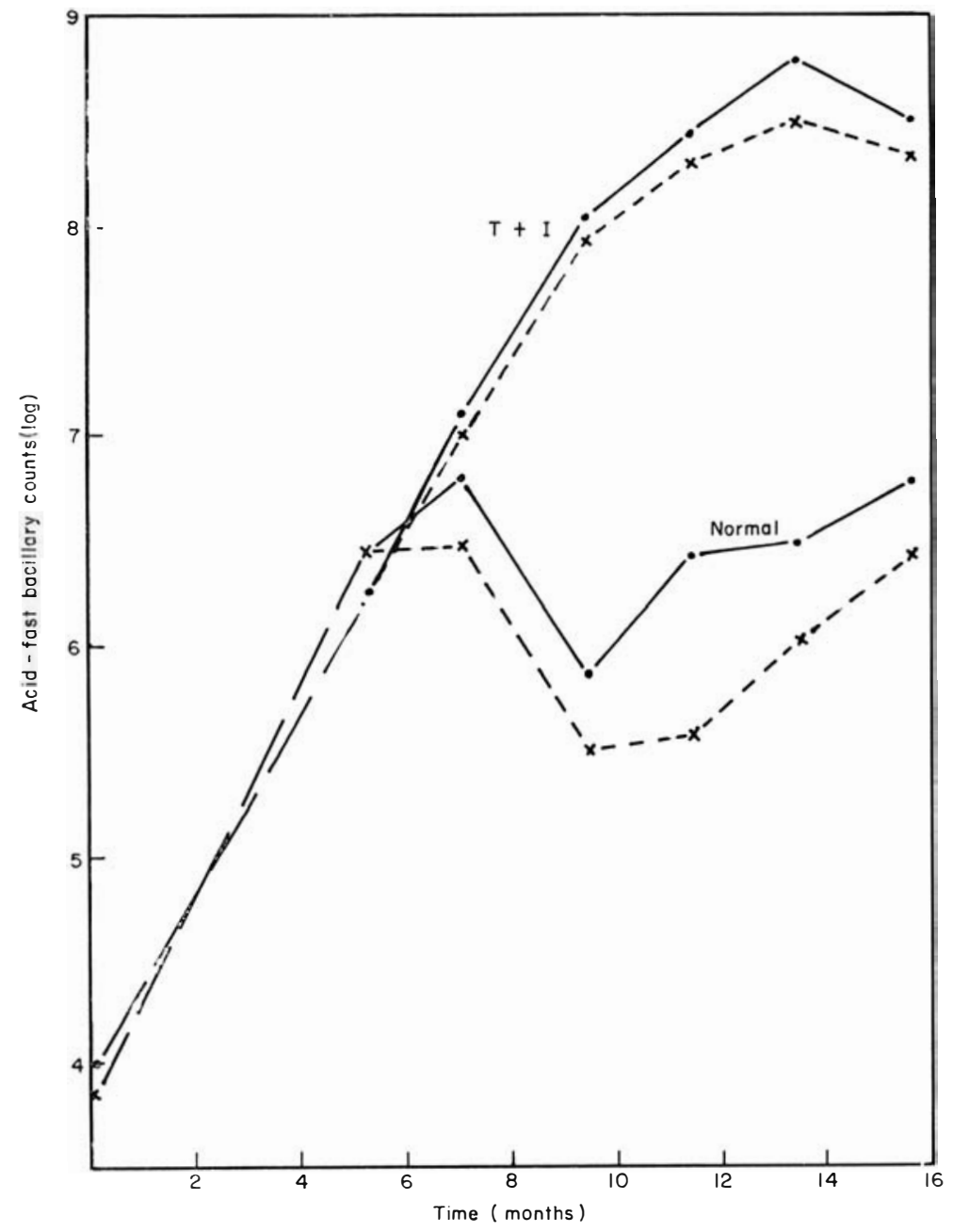

Fig. 3

Growth curves of Myco. leprae in the footpads of normal and thymectomized, irradiated $(\mathrm{T}+\mathrm{I}$; dose $900 \mathrm{r})$ mice inoculated with $10^{4}$ bacilli (data taken, by permission, from Rees et al., 1967). Continuous lines, total number of Myco. leprae; broken lines, number of viable Myco. leprae. 
sites of predilection are in the skin of the ears, hind and fore paws, the tail and also the nose (Table 4).

\section{TABLE 4}

Localization and yield of Myco. leprae in a thymectomized, irradiated* mouse 19 months after the intravenous injection of $3 \times 10^{7}$ bacilli

\begin{tabular}{|c|c|c|c|}
\hline $\begin{array}{l}\text { Organ } \\
\text { or } \\
\text { tissue }\end{array}$ & $\begin{array}{l}\text { Estimated } \\
\text { Per site } \\
\left(\times 10^{6}\right)\end{array}$ & $\begin{array}{l}\text { yield of bacilli } \\
\text { Percertage of } \\
\text { total yield }\end{array}$ & $\begin{array}{c}\text { Degenerate } \\
\text { bacilli } \\
(\%)\end{array}$ \\
\hline \multicolumn{4}{|l|}{ Footpads: } \\
\hline Hind & 1740 & 18 & 56 \\
\hline Fore & 960 & 10 & 60 \\
\hline Total & 2700 & 95 & 59 \\
\hline Ears & 4800 & 49 & 50 \\
\hline Nose & 1800 & 18 & 61 \\
\hline Muscle of leg & 76 & 0.8 & 30 \\
\hline Muscle of body & 160 & 1.6 & 31 \\
\hline Skin of tail & 21 & 0.2 & 89 \\
\hline Skin of body & 5 & 0.05 & 55 \\
\hline Liver & 130 & 1.3 & 82 \\
\hline Spleen & 53 & 5.0 & 87 \\
\hline Lung & 10 & 0.1 & 70 \\
\hline Total & 9755 & & \\
\hline
\end{tabular}

*Dosage: $900 \mathrm{r}$.
The same rigorously controlled criteria have been used to identify Myco. leprae in the enhanced infections that were used in normal animals and have included testing the sensitivity of the organisms to diaminodiphenylsulfone (Rees and Weddell, 1968; Rees et al., 1967) and the production of lepromin (Draper, Rees and Waters, 1968).

In addition to the higher yields of bacilli from such animals it has been shown that later in the infection there is frequently nodular swelling of the footpads (Fig. 4) and the histology of the lesions replicates that seen in patients with lepromatous or borderline-type leprosy (Fig. 5) (Rees and Weddell, 1968; Rees et al., 1967). Thus there is heavy infection of the peripheral nerves in the skin sites referred to (Fig. 6). Positive smears can be obtained from nasal swabs and the histological picture shows typical foam cells and degenerative changes in some of the infected peripheral nerves (Rees and Weddell, 1968). There is increasing evidence that these changes occur with the slow and partial recovery

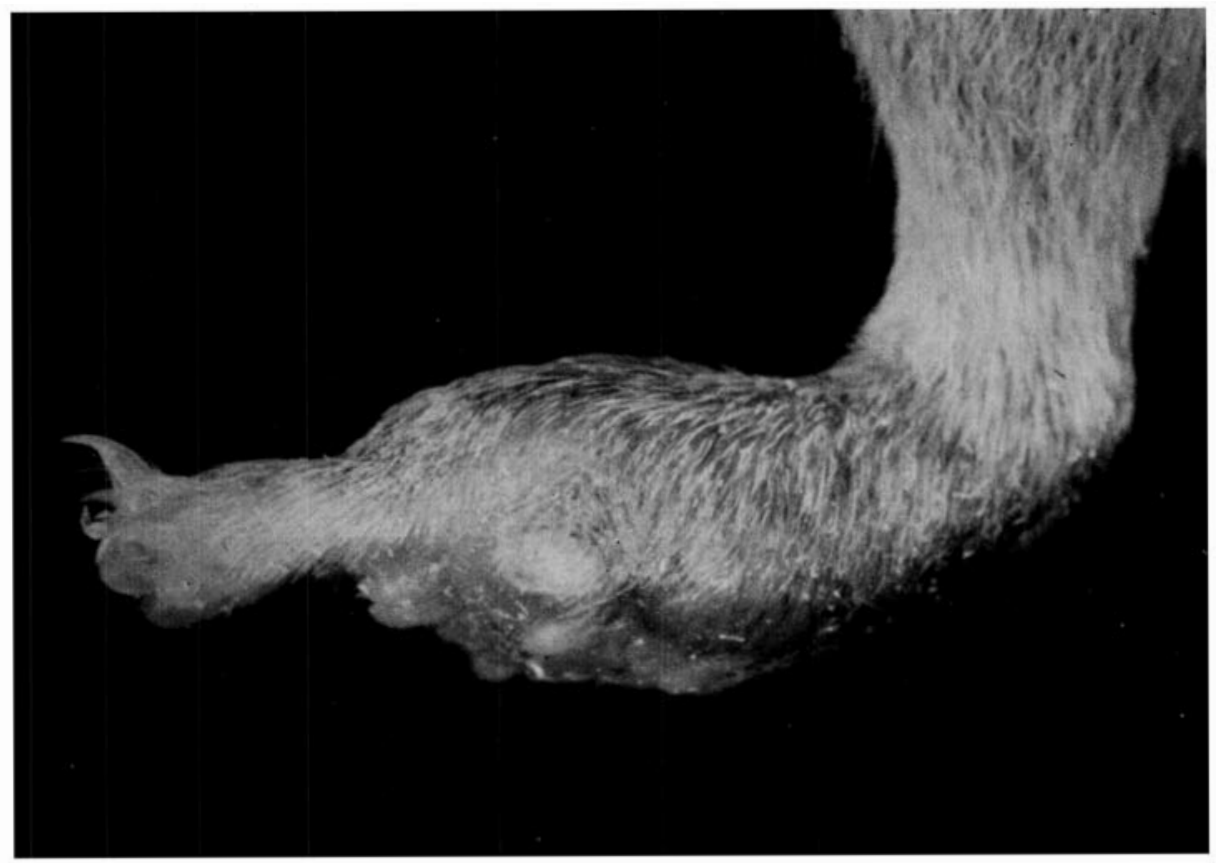

FIG. 4

Nodular swelling of hind footpad of a thymectomized, irradiated mouse inoculated locally with $10^{4}$ Myco. leprae 9 months previously. 


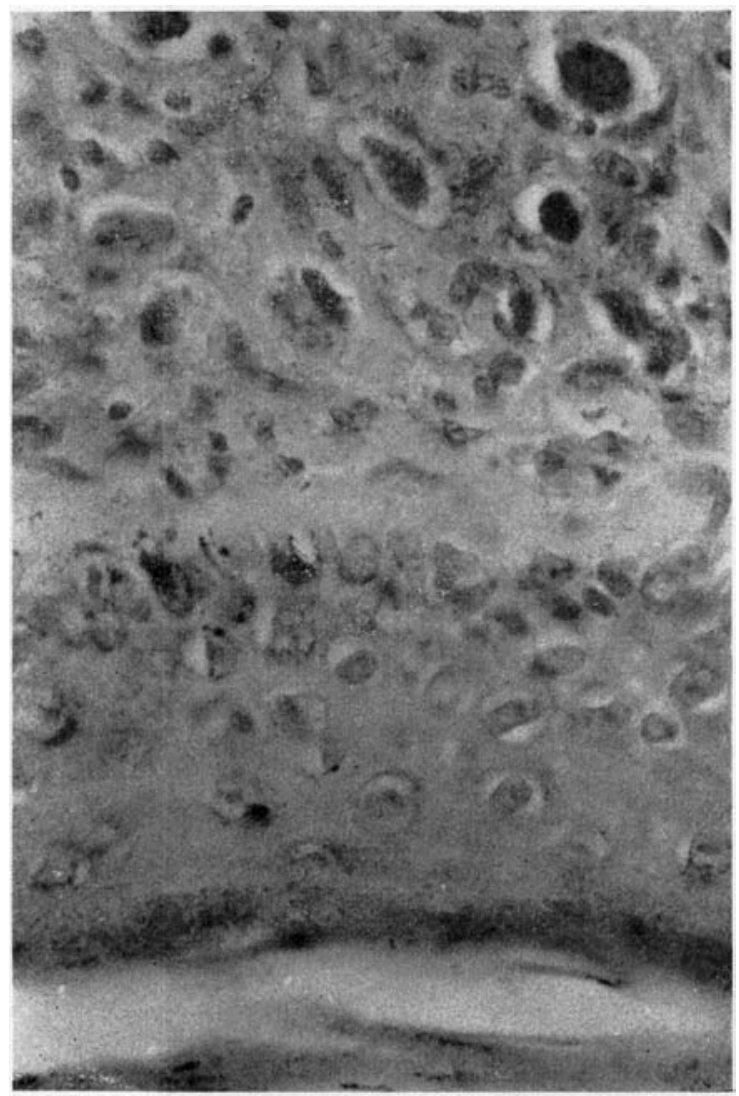

FIG. 5

Skin frcm tl.e nociular, swollen footpad of a thymectomized, irradiated mouse inoculated 8.5 months previously with $10^{8}$ Myco. leprae. Globi loaded with bacilli and foam (Virchow's cclls) are seen in the dermis that is separated by a clear zone from the epidermis. These features replicate those seen in lepromatous leprosy in man. Stained: hacmatoxylin and coll carbol fuchsin. $\times 216$ J.

of the immunological capacity of the animals and can be enhanced in animals with established infections by the donation of immunologically competent syngeneic lymphoid cells from normal mice (Fig. 7) (Rees and Weddell, 1968).

\section{FUTURE PROSPECTS}

The successful transmission of human leprosy to animals (with the prospect of maintaining the infection indefinitely by serial passage) and the reproduction of some of the major characteristics of the human disease in iaboratory animals by

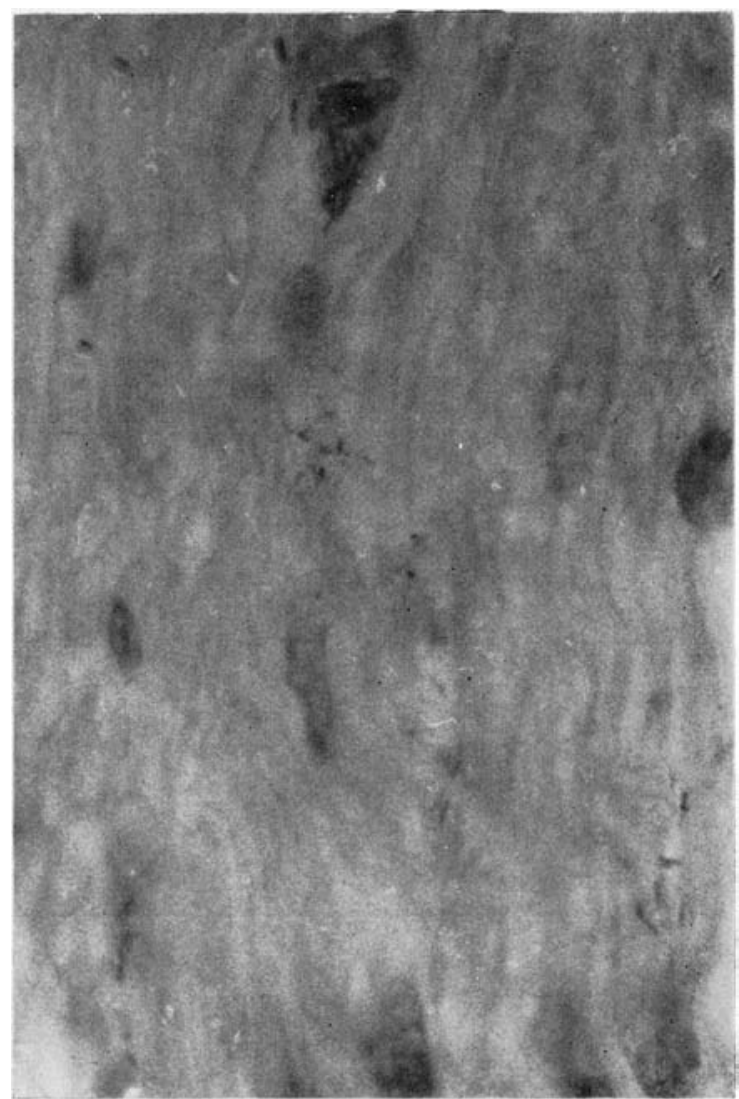

FIG. 6

Medial plantar nerve from the same mouse as in Fig. 5 to show Schwann cells infected with Myco. leprae. Stained: haematoxylin and cold carbol fuchsir. $\times 4500$.

reducing their immunological capacity, provide, for the first time, a means of studying Myco. leprae in the laboratory.

\section{Chemothcrapeutic studies}

The enhanced infection provides a more rapid method for screening new drugs against Myco. leprae and for applying the more quantitative and kinetic methods already developed in normal mice for studying the action of antileprosy drugs (Shepard, 1967a). In particular, the larger infections obtained in thymectomized, irradiated mice will provide a more sensitive method for determining and comparing the bacteriostatic, as well as the bactericidal, 


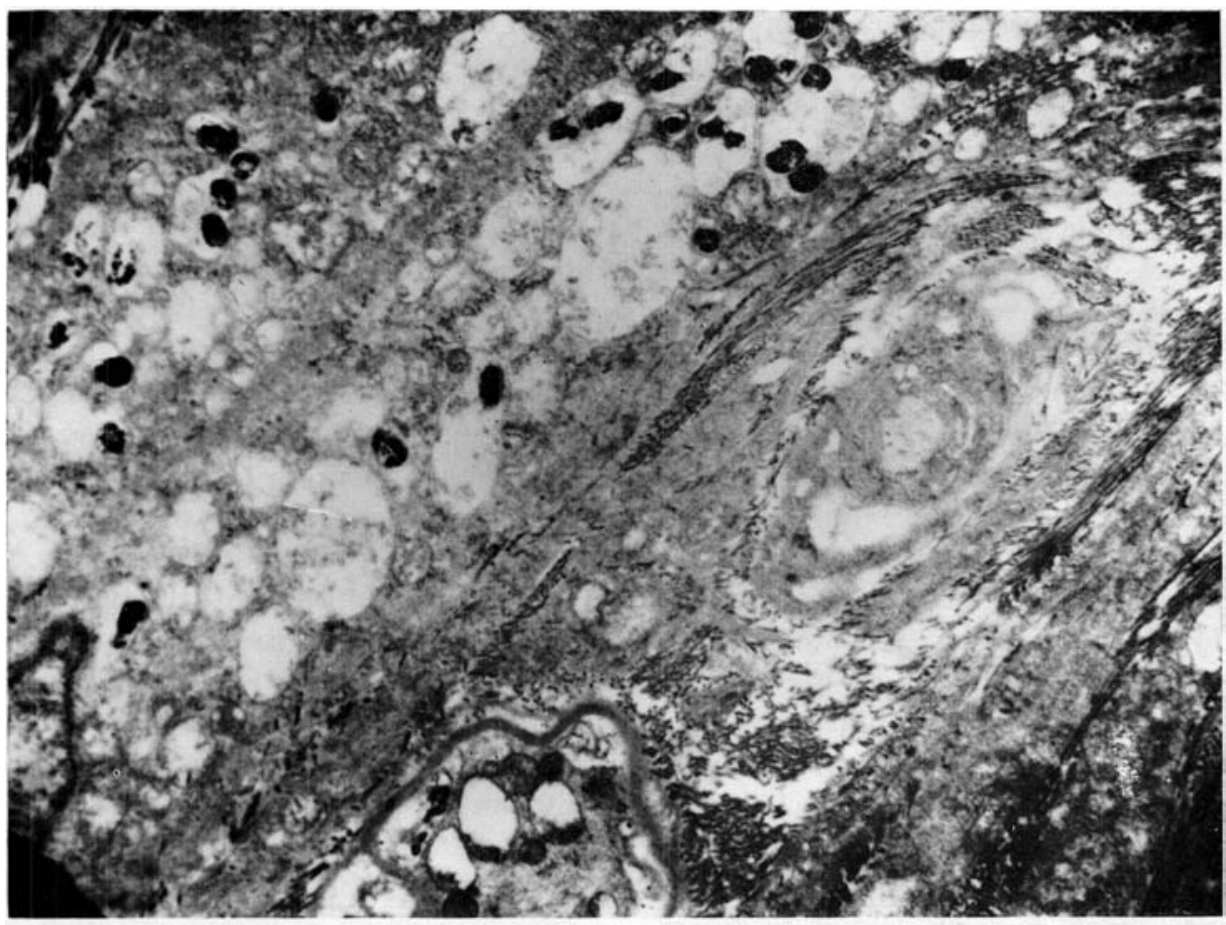

FIG. 7

Electron photomicrograph of dermis from ear of thymectomized, irradiated mouse inoculated with $10^{7}$ Myco. leprae locally in both ears and footpads 15 months previously and given syngeneic lymphoid cells from a normal mouse 5 months before this preparation was made. (The degeneration of nerve axons, myelin rings, and Schwann cells in 2 myelinated nerve fibres can be seen.) $\times 31500$

effects of drugs on Myco. leprae. Although the application of the MI to chemotherapeutic studies in man indicates that a very high proportion of bacilli in the skin are killed, by diaminodiphenylsulfone, for example, within a period of 3 to 6 months, there is strong clinical evidence that patients relapse unless diaminodiphenylsulfone treatment is maintained for several years (Quagliato et al., 1961). One possible explanation is that there are specific sites in the body in which diaminodiphenylsulfone and other antileprosy drugs are ineffective, or less effective, and that such sites provide a source of viable organisms. There are suggestions from histological studies on human tissues that arrectores pili muscles and Schwann cells may still harbour healthy bacilli when those in surrounding tissues are very degenerate. The heavy and generalized infection which can be obtained in intravenously inoculated thymectomized, irradiated mice provides an ideal model for investigating these possibilities since the cellular pattern of infection exactly mimics that used in man, including parasitization of both muscle and Schwann cells. By treating such animals with antileprosy drugs, including drugs labelled with radiactive isotopes, it should be possible to determine both the distribution of the drugs and of degenerate and normal bacilli, at an intracellular level.

Emergence of drug-resistant strains of $\mathrm{Myco.}$ leprae

The footpad infection technique in normal and thymectomized, irradiated mice is the only method available at present for detecting the 
emergence of drug-resistant strains of Myco. leprae and the method could now be used to survey the importance of drug resistance on a world-wide basis. Because of the increasing use of low-dose regimens of diaminodiphenylsulfone, there is obviously a danger of diaminodiphenylsulfone resistance emerging. Under field conditions, however, if such resistance emerged it might remain undetected by the routine clinical and bacteriological methods until it had reached serious proportions. Because diaminodiphenylsulfone is the standard form of treatment throughout the world, such an occurrence would be disastrous to the control of leprosy. Every effort should therefore be made now to devise suitable experimental models which might be used to predict the rate of emergence of diaminodiphenylsulf one-resistant strains of Myco. leprae in animals receiving decreasing doses of the drug. The bacterial populations in an established infection in intravenously inoculated, thymectomized, irradiated mice, would be large enough to detect resistance since such mice have a bacterial population of $10^{10}$ and drug-resistant mutants could be expected in a proportion of $1: 10^{7}$.

\section{Routes of infection}

The routes of infection for leprosy in man are still unknown and the much more susceptible, thymectomized, irradiated mice provide an experimental model for investigating this important problem. The nose, upper respiratory tract, alimentary tract and skin are all routes of infection that should be studied. Moreover, because it is known that thymectomized, irradiated mice heavily infected with Myco. leprae excrete bacilli from their nasal mucosa (Rees and Weddell, 1968), they could be used as "open cases" to determine their infectiousness for highly susceptible but non-infected thymectomized, irradiated mice, housed in the same cages.

\section{Sources of infection other than man}

There has been much discussion on whether vectors, either insect or mammalian, could be involved in the transmission of leprosy from man to man and whether any domestic or wild animals can be infected with Myco. leprae and therefore be a source of bacilli to infect man. The successful transmission of human leprosy to normal or thymectomized, irradiated mice might be used in 2 ways to study these possibilities. The mouse footpad technique could provide, for the first time, a reliable method of identifying as Myco. leprae any non-cultivable, acid-fast bacilli isolated from potential vectors. On the other hand, and perhaps even more important, there is the observation that the intravenous inoculation of Myco. leprae into normal mice can produce, towards the end of their life, an infection of the nose and the paw skin. Because the inoculation of Myco. leprae into the footpads of rats results in a pattern of infection similar to that in mice, it is likely that both species are equally susceptible to the human leprosy bacillus. It is possible, therefore, that wild mice and rats in leprosy endemic areas could be infected with Myco. leprae and thus be a source of human infection. Since both rats and mice are present in large numbers in all epidemic and endemic leprosy areas throughout the world, it is suggested that this possibility should be investigated by sample surveying.

Application of enhanced infection for studying the pathogenesis of human leprosy

Leprosy in man presents a wide clinical spectrum ranging from the tuberculoid type, where there are few bacilli and the patient has a high degree of immunity, to the lepromatous form, where there are many bacilli and the patient has little or no resistance. Superimposed on these very variable clinical forms is the common feature that peripheral nerves are infected. Myco. leprae is the only species of mycobacterium known to infect nerves in either man or animals and the extent of damage to the infected nerves appears to depend on the immunological capacity of the host. Thus, in tuberculoid-type leprosy, infection of nerves results in the destruction of axons, whereas in lepromatous leprosy, the nerves can be heavily infected with bacilli without damage to the axons. The "target cell" for parasitization by 
Myco. leprae within nerves is the Schwann cell. In addition to the variable clinical picture "reactional" episodes may occur and on these occasions the existing lesions, or new ones, present as sites of acute inflammation. These episodes are likely to have an immunological basis; certainly, an increase in the immunological capacity of the patient must play a major role in one type of reaction since it is followed by a shift in the clinical picture from the lepromatous towards the tuberculoid form of the disease. The term "reversal reaction" has been applied to such a shift.

The importance of nerve involvement in all forms of leprosy, together with the very wide range of clinical, bacteriological and histological forms, and the way in which each seems to be dependent upon fine differences in the immunological capacity of the patient, have been stressed in order to illustrate the complexity of leprosy in man. On account of the chronicity and complex nature of the disease in man, it is probable that the final elucidation of the pathogenesis of human leprosy will be achieved only if contributions are made from the experimental studies and such contributions can only be made if the human disease can be duplicated in experimental animals. This prerequisite seems likely to be achieved because already the inoculation of Myco. leprae into mice subjected to thymectomy and total body irradiation has reproduced completely the lepromatous type of disease seen in man (Rees and Weddell, 1968).

These 2 areas of immunological research in leprosy are, of course, importantly related. Mice have been shown to develop lepromatous-type infection when they are subjected to procedures (thymectomy and irradiation) that produce a profound and long-lasting immunological depression, and the immunological depression in lepromatous patients has been made clear by well-tried immunological procedures (Int. J. Leprosy, 1968). Fortunately, it is possible to increase the immunological capacity of treated mice at will (by the intraperitoneal inoculation of syngeneic lymphoid cells from normal mice) and already preliminary results of such mani- pulations show that the progressive form of lepromatous leprosy can be halted or that reversal reactions can be produced which result in a shift from the lepromatous form of the disease to the tuberculoid form seen in man (Rees and Weddell, 1968). Therefore, there is every reason to believe that these models can and should be developed in order to provide means to study the pathogenesis of the different forms of human leprosy, to study the etiology of nerve involvement and damage and to study the role of immunology in these processes.

\section{REFERENCES}

ADAms, A. R. D. and waters, M. F. R. (1966). Brit. med. J. $i i, 872$.

Brown, J. A. K. and stone, м. м. (1966). Brit. med. J. $1,7$.

Brown, J. A. K., STONe, M. M. aill SUTherLAND, I. (1968). Brit. med. J. 1, 24.

CHANG, Y. T. (1960). Fed. Proc. 19, 385.

DRAPER, P., REES, R. J. W. and WATERS, M. F. R. (1968). Clin. exp. Immunol. 3, 809.

FENNER, F. (1957). Amer. Rev. Tuberc. 76, 76.

FRANCIS, J. and spinks, A. (1950). Brit. J. Pharmacol. $5,565$.

Gaugas, J. M. (1967). Brit. J. exp. Path. 48, 417.

Glazko, A. J. et al. (1968). Amer. J. trop. Med. Hyg.

$17,465$.

HART, P. D'A, REES, R. J. W. and VALENTINE, R. C. (1962). J. Path. Bact. 84, 105.

HILsON, G. R. F. (1965). Int. J. Lepr. 33, 662.

HILSON, G. R. F. and ELEK, s. D. (1957). Int. J. Lepr. 25,380 .

HOBВY, G. L., HANKS, J. H., DONIKIAN, M. A. and BaCkerman, т. (1954). Amer. Rev. Tuberc. 69, 173. Int. .J. Lepr. (1968) 36, 87.

Konopka, E. C. etal. (1955). Proc. Soc. exp. Biol. (N.Y.) $89,388$.

MCFAdZeAN, J. A. and valentine, R. C. (1959). Trans. roy. Soc. trop. Med. Hyg. 53, 414.

Nishimura, s. et al. (1964). La Lepro 33, 245.

PETtit, J. H. S. and REES, R. J. W. (1964). Lancet ii, 673. PETTIT, J. H. S., REES, R. J. W. and RIDLEY, D. S. (1966). Int. J. Lepr. 34, 375.

QUAGliato, R., Berquo, E. and Leser, W. (1961). Rev. bras. Leprol. 29, 19.

REES, R. J. W. (1957). E. Afr.med. J. 34, 361.

rees, R. J. W. (1964). Brit. J . exp. Path. 45, 207.

REES, R. J. W. (1965a). Nature, Lond. 211, 657.

REES, R. J. W. (1965b). Int. J. Lepr. 33, 646.

REES, R. J. W. (1967a). Trans. roy. Soc. trop. Med. Hyg. 61,581 . 
REES, R. J. W. (1967b). Int. J. Lepr. 35, 625.

REES, R. J. W. and GARBUTt, E. W. (1962): Brit. J. exp. Path. 34, 221.

ReEs, R. J. W. and valentine, R. C. (1962). Int. J. Lepr. 30, 1 .

REES, R. J . W., VALENTINE, R. C. and WONG, P. C. (1960). J. gen. Microbiol. 22, 443.

REES, R. J. W. and WATERS, M. F. R. (1963). Applicability of experimental murine leprosy to the study of human leprosy. In: The Pathogenesis of Leprosy, London: Churchill, p. 39 (Ciba Foundation Study Group No. 15).

REES, R. J. W. and WEDDELL, A. G. M. (1968). Ann. N.Y. Acad. Sci. 154, 214.

ReEs, R. J. W. and Wong, P. C. (1958). Nature, Lond. 181,359 .

REES, R. J. W. et al (1967). Nature, Lond. 215, 599.

Scientific Meeting on Rehabilitation in Leprosy (1961). Wld Hlth Org. techn. Rep. Ser. 221.

SHEPARD, C. C. (1960a). Amer. J. Hyg. 71, 147.

SHEPARD, C. C. (1960b). J. ex. Med. 112, 445.

SHEPARD, C. C. (1964). Science 146, 403.

Shepard, C. C. (1965a). Amer. J. Epidemiol. 81, 150.

SHEPARD, c. c. (1965b). Int. J. Lepr. 33, 657.

SHEPARD, C. C. (1966). J. Immunol. 96, 279.

SHEPARD, C. C. (1967a). Int. J. Lepr. 35, 429.

SHEPARD, C. C. (1967b). Int. .J. Lepr. 35, 616.
Shepard, c. C. and ChANG, Y. T. (1962). Proc. Soc. exp. Biol. (N.Y.) 109, 636.

SHEPARD, C. C. and CHANG, Y. T. (1964). Int. .J. Lepr. $32,260$.

SHEPARD, C. C. and CONGDON, c. c. (1968). Int. J. Lepr. 36, 224 .

SHEPARD, C. C. and GUINTo, R. s. (1963). Int. J. Lepr. $31,535$.

SHEPARD, C. C. and hABAS, J. A. (1967). J. Bact. 93, 790.

SHEPARD, C. C. and MCRAE, D. H. (1965). .J. Bact. 89, 365.

Shepard, C. c. and Ribi, E. (1968). Proc. Soc. exp. Biol. (N.Y.) 127, 517.

Technical Committee on Pathology and Experimental Transmission (1963). Int. J. Lepr. 31, 473.

thompson, P. E., oleszewsin, B. and WAitz, J. A. (1965). Amer. J. trop. Med. 14, 343.

WALlACE, J. H., ELEK, S. D. and HANKS, J. H. (1958). Proc. Soc. exp. Biol. (N.Y.) 97, 101.

WATERs, M. F. R. and Niven, J. S. F. (1965). Int. J. Lepr. 33, 297.

WAters, M. F. R. and Niven, J. S. F. (1966). Brit. .J.exp. Path. 47, 86.

WATERS, M. F. R. and REES, R. J. W. (1962). Int. J. Lepr. 30, 266.

WATERS, M. F. R., REES, R. J. W. and SUTHERLAND, I. (1967). Int. J. Lepr. 35, 311.

WIERSEMA, J. P., BINFORD, C. H. and CHANG, Y. T. (1965). Int. J. Lepr. 35, 617. 